\title{
Mixed Chromate and Molybdate Additives for Cathodic Enhancement in the Chlorate Process
}

\author{
Vera Smulders ${ }^{1} \cdot$ Adriano S. O. Gomes $^{2} \cdot$ Nina Simic $^{2} \cdot$ Bastian Mei $^{1}\left[\right.$ ( $\cdot$ Guido Mul $^{1}$
}

Accepted: 6 April 2021 / Published online: 16 April 2021

(c) The Author(s) 2021

\begin{abstract}
The economic viability of the electrochemical chlorate process depends on toxic chromate to induce cathodic selectivity to hydrogen and mitigate reduction of hypochlorite or chlorate. In this study, it is shown that performance of a pilot plant for chlorate production can be sustained when a 1000-fold reduction in chromate concentration is compensated by addition of molybdate. Laboratory measurements employing a Quartz Crystal Microbalance suggest growth of a nanometre-thick hybrid Mo-Cr-oxide film to induce cathodic selectivity. An optimized energy efficiency for pilot plant operation was obtained using $0.8 \mathrm{mM}$ molybdate and $27 \mu \mathrm{M}$ chromate, balancing formation of an effective oxide layer and undesired Mo-induced decomposition of hypochlorite to oxygen in solution. Refinement at the pilot scale level is expected to further optimize the energy consumption, thereby increasing safety aspects and the economic viability of chlorate production.
\end{abstract}

Keywords Cathode selectivity $\cdot$ Hydrogen $\cdot$ Industrial electrochemistry $\cdot$ Electrolyte additives $\cdot$ Chlorate $\cdot$ Electrochemical Quartz Crystal Microbalance (eQCM)

\section{Introduction}

The production of sodium chlorate is one of the presently largest industrial electrochemical processes in operation [1]. Chlorate is made by electrochemical oxidation of chloride to chlorine, followed by hydrolysis of chlorine and formation of chlorate by disproportionation of hypochlorite and hypochlorous acid. To allow highly selective cathodic formation of hydrogen in a membrane-free cell design, thermodynamically favourable reduction of solution-dissolved intermediates (hypochlorite and hypochlorous acid) and chlorate should be prevented [2]. To promote the hydrogen evolution reaction (HER) selectivity, sodium dichromate is used as an additive in the electrolyte, which is reduced on the cathode, usually mild steel, to a nanometre-thick film

Bastian Mei

b.t.mei@utwente.nl

Guido Mul

g.mul@utwente.nl

1 PhotoCatalytic Synthesis Group, Faculty of Science and Technology, MESA Institute for Nanotechnology, University of Twente, Meander 229, P.O. Box 217, 7500, AE, Enschede, The Netherlands

2 Nouryon, 445-80 Ale, Bohus, Sweden of $\mathrm{Cr}(\mathrm{III}) \mathrm{O}_{x} \times \mathrm{nH}_{2} \mathrm{O}$ (hereafter denoted as $\mathrm{CrO}_{x}$ ), greatly improving process efficiency [3].

With the implementation of the REACH Annex XIV legislation, toxic dichromate requires special authorization before use in any industrial process [4]. A long-term viable solution for chlorate plants in the European Union is urgently needed and requires at least a significant reduction in chromate concentration or ideally the full replacement of chromate by an alternative agent forming a cathode with high HER selectivity.

To find a suitable replacement for dichromate, various candidates including polymers [5], rare earth metal salts [6, 7], or other multivalent cations [8-10] were tested in benchscale experiments. Considering similarities between the functionality of $\mathrm{CrO}_{x}$ in chlorate production and protecting steel from corrosion [11], molybdate appears to be another promising candidate $[12,13]$. Molybdate has favourable characteristics, such as cathode activation for HER in alkaline media [13, 14], in situ film formation [15], buffering in a range suitable for chlorate formation[13] and inhibiting the oxygen reduction reaction (ORR) [15], and was also shown to inhibit oxychloride reduction [16]. Furthermore, it is known that molybdate is safer and more environmentally friendly than dichromate. 
Nevertheless, in the absence of dichromate, it has also been shown that a strong correlation exists between molybdate and oxygen content $\left(\mathrm{O}_{2} \%\right)$ in the cell gas $[13,17]$. Given the risk of formation of explosive mixtures, excessive use of molybdate must be avoided, and fine tuning of the molybdate concentration is important [13]. In fact, using Maxphase cathodes, molybdate in the concentration range of 7 to $70 \mu \mathrm{M}$ was found to promote the HER, without considerably increasing the oxygen content in the cell gas [17]. Furthermore, molybdate was particularly effective in combination with a second additive, such as $\mathrm{Cr}$ [16], or Fe [14]. However, the origin of the effectiveness has not been revealed. Additional analysis of the properties of electrolyte mixtures is required [17], and transition from benchtop laboratory experiments to pilot or even industrial plants is still lacking. This is particularly important, as differences in reactor geometry, time scale, mass transport properties and the ratio of reactor-volume to electrode surface render the scale-up non-trivial $[18,19]$.

In this work, laboratory-scale experiments are compared to process operation at pilot scale, focusing at low concentrations of chromate $(\mu \mathrm{M}$ range compared to $\mathrm{mM}$ range in current industrial chlorate production) in combination with molybdate. It is shown that the impact of electrolyte-additives is described best using the cathodic and anodic current efficiencies, the oxygen and hypochlorite production and the full cell potential. Film deposition is revealed by quartz crystal microbalance (QCM) measurements, and the HER kinetics and electrode selectivity are confirmed on the basis of rotating ring disc electrode (RRDE) experiments. Molybdate deposition at the cathode is suppressed in the presence of chromate, leading to a hybrid behaviour of the resulting film. The analysis revealed that electrolyte compositions of $0.8 \mathrm{mM}$ molybdate with $27 \mu \mathrm{M}$ chromate are most ideal for chlorate production. Several aspects of the translation of fundamental laboratory results to pilot-scale operation will be discussed, highlighting that considerations of scale-up should already be considered in the early stages of process development.

\section{Experimental}

\section{Pilot-Scale Experimentation}

Experiments were performed in a pilot plant with an interelectrode gap of $3 \mathrm{~mm}$ as schematically shown in Fig. 1.
Fig. 1 Schematic of the pilot plant and electrode stack
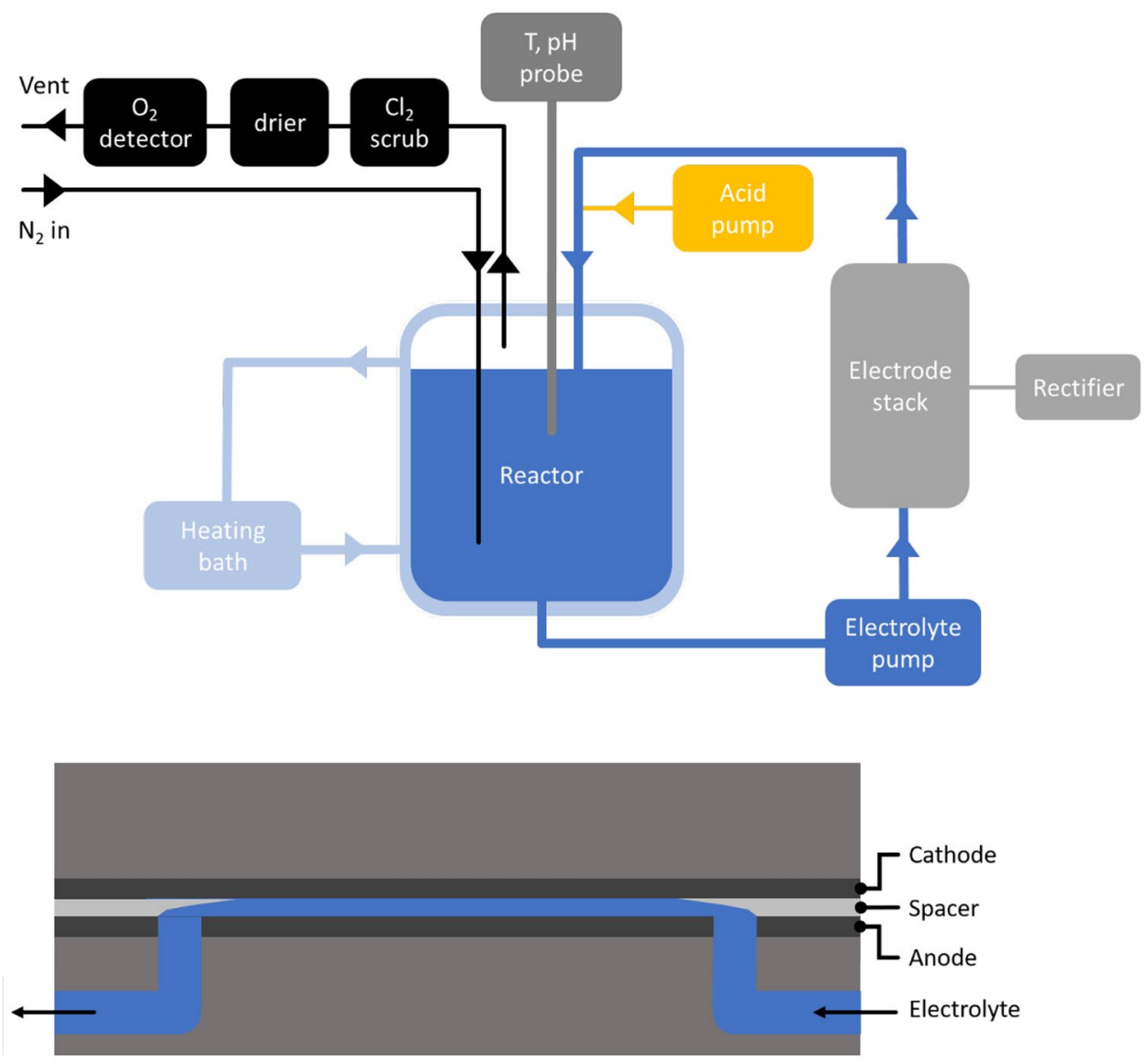
A detailed description of the setup and data validation is described elsewhere [20].

For pilot-scale experiments, a dimensionally stable anode (DSA) and a Ti plate were used as anode and cathode, respectively. Though Ti cathodes are less frequently used than mild steel cathodes, here, Ti cathodes are used due to stability and reproducibility. Contrarily, mild steel cathodes heavily corrode after a stop, and release Fe in the electrolyte; therefore, it is quite difficult to reproduce the surface structure obtained in specific experiments, and disentangling effects induced by specific ions, such as Mo, will be cumbersome due to the possible interaction with dissolved Fe. Moreover, the steady-state operation for corroded steel electrodes is only achieved after long-term operation, even in the presence of $\mathrm{Cr}(\mathrm{VI})$ $\left(5 \mathrm{~g} \mathrm{dm}^{-3}\right)$. Contrarily, Ti activates within the first few minutes, rendering Ti electrodes more suitable for the purpose of this study. Electrodes and gaskets ( $\mathrm{Si}$, DensiQ) were cleaned by rinsing with acetone or water, prior to first use. All experiments were performed using 1.1 $\mathrm{dm}^{3}$ of electrolyte circulated at $160 \mathrm{~mL} \mathrm{~min}^{-1}$ using an Iwaki Magnet Pump. The electrolyte temperature (348 K) was controlled by a Laude Eco Silver thermostatic bath. A Mettler Toledo $\mathrm{pH} 2100 \mathrm{e} \mathrm{pH}$ meter and Grundfos Alldos DDA acid pump with $2 \mathrm{M} \mathrm{HCl}$ (Scharlau, reagent grade) were used to maintain a constant $\mathrm{pH}$ of 6.5. The reactor was flushed with $60 \mathrm{~mL} \mathrm{~min}^{-1} \mathrm{~N}_{2}$, and the gas was analysed for $\mathrm{O}_{2}$ content using a Servomex Series 1100 (see SI for full details).

The standard electrolyte was composed of $5.5 \mathrm{M}$ $\left(580 \mathrm{~g} \mathrm{dm}^{-3}\right) \mathrm{NaClO}_{3}$ (Nouryon) and $2 \mathrm{M}\left(120 \mathrm{~g} \mathrm{dm}^{-3}\right)$ $\mathrm{NaCl}$ (Scharlau, ExpertQ grade) in deionized water. Chlorate was recrystallized to remove all chromate contamination. As electrolyte-additives, $\mathrm{Na}_{2} \mathrm{Cr}_{2} \mathrm{O}_{7} \times 2 \mathrm{H}_{2} \mathrm{O}$ (Sigma Aldrich, 99.5\%; concentrations $2.7,27$ or $270 \mu \mathrm{M}$ ) and $\mathrm{Na}_{2} \mathrm{MoO}_{4}$ (Sigma, 99.5\%; concentrations $0.8,8,40$ and $80 \mathrm{mM}$ ) were used. All individual experiments were run for at least $90 \mathrm{~min}$ at current densities of $3 \mathrm{kA} \mathrm{m}^{-2}$ before electrolyte compositions were changed. To allow safe handling during molybdate or chromate addition, the current was stopped, and the cell was flushed with $150 \mathrm{~mL} \mathrm{~min}^{-1}$ of $\mathrm{N}_{2}$. Afterwards, experiments were resumed at a current density of $3 \mathrm{kA} \mathrm{m}^{-2}$.

The hypochlorite concentration in the electrolyte was determined by extracting $19 \mathrm{~mL}$ of electrolyte. A syringe that contained $5 \mathrm{~mL} 5 \mathrm{M} \mathrm{NaOH}$ (Scharlau, reagent grade) was used to prevent hypochlorite decomposition. Five millilitres of this mixture was combined with $10 \mathrm{~mL} 0.5 \mathrm{M}$ acetate buffer (HAc, Scharlau 99.8\%, and NaAc, Merck, $99-101 \%), 10 \mathrm{~mL} 0.1 \mathrm{M} \mathrm{KI}$ (Scharlau, reagent grade) and $50 \mathrm{~mL} \mathrm{H}_{2} \mathrm{O}$. Thiosulfate (Merck, p. a.) was used to perform titration using a Metrohm 775 Dosimat with starch (Sigma Aldrich, ACS reagent) as an indicator. Each titration was performed in triplicate.

\section{Laboratory-Scale Experimentation}

Rotating ring disc electrode (RRDE) experiments were performed using a PINE research WaveVortex 10 RRDE, with a ChangeDisc tip containing a Pt ring electrode and interchangeable Ti discs were used as working electrode. The discs were subsequently polished with 0.3 and $0.05 \mu \mathrm{m} \mathrm{Al}$ paste, rinsed and sonicated for $10 \mathrm{~min}$ in Milli-Q to remove deposited films. A Pt wire (Alpha Aesar, > 99.99\%) was used as counter electrode. The electrolyte was composed of $1 \mathrm{M}$ $\mathrm{NaOH}$ and $2 \mathrm{M} \mathrm{NaCl}$, and solution additives resembling the concentration of the pilot plant measurements were added when required. QCM experiments were performed using a Gamry eQCM $10 \mathrm{M}$ at $5 \mathrm{MHz}$. The sensors were $\mathrm{Au}-\mathrm{Ti}$ crystals from MicroVacuum. The cell was cooled to $15{ }^{\circ} \mathrm{C}$ using a Julabo F12 water bath.

\section{Results and Discussions}

\section{Pilot Plant Operation}

The effectiveness of molybdate and chromate additives in the chlorate process was studied at the pilot-plant scale. The performance parameters for the current state-of-the-art chlorate electrolyte, containing $5 \mathrm{~g} \mathrm{dm}^{-3}$ sodium dichromate (or $21 \mathrm{mM}$ ), are summarized in Table 1 .

An overview of the performance parameters obtained for the different electrolyte compositions is shown in Fig. 2. Performance was evaluated by comparing each measurement to the current state-of-the-art process conditions (Fig. 2, red dotted lines). Experimental errors, as indicated by the error bars, were obtained by performing measurements in triplicate. The bottom axis shows the applied concentration of chromate and the top axis (blue) the applied concentration of molybdate. The data for variable chromate-only concentrations are indicated by the dashed lines, of molybdate (with $27 \mu \mathrm{M}$ chromate) in blue and in black (continuous) the chromate data in the presence of $80 \mathrm{mM}$ molybdate.

Table 1 Performance parameters measured in the pilot plant for the current state-of-the-art chlorate electrolyte containing $21 \mathrm{mM}$ $\left(5 \mathrm{~g} \mathrm{dm}^{-3}\right)$ dichromate, $5.5 \mathrm{M}\left(580 \mathrm{~g} \mathrm{dm}^{-3}\right) \mathrm{NaClO}_{3}$ and $2 \mathrm{M}$ $\left(120 \mathrm{~g} \mathrm{dm}^{-3}\right) \mathrm{NaCl}$ using Ti and DSA cathode and anode, respectively. The temperature was maintained at $348 \mathrm{~K}$, and chlorate synthesis was performed at current density of $3 \mathrm{kA} \mathrm{m}^{-2}$

\begin{tabular}{ll}
\hline Parameter & Value \\
\hline Cathodic current efficiency (\%) & 97.0 \\
Anodic current efficiency (\%) & 96.3 \\
Cell potential (V) & 3.38 \\
Energy efficiency $\left(\mathrm{kWh} \mathrm{ton}^{-1}\right)$ & 5470 \\
{$[\mathrm{NaClO}]\left(\mathrm{mM}\left(\mathrm{g} \mathrm{dm}^{-3}\right)\right)$} & $18(1.3)$ \\
$\mathrm{O}_{2}$ formation $\left(\mu \mathrm{M} \mathrm{s}^{-1}\right)$ & 0.71 \\
\hline
\end{tabular}




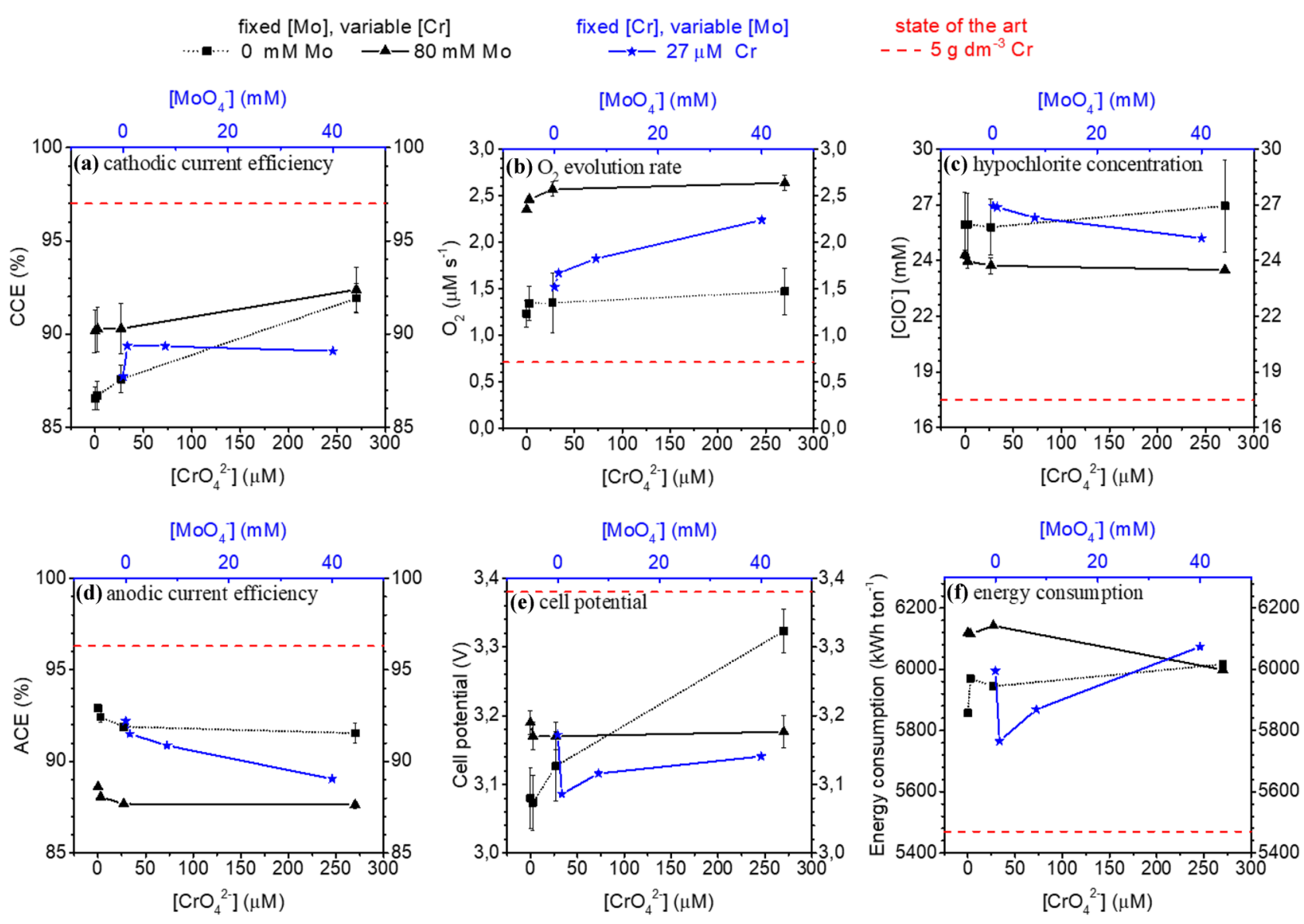

Fig. 2 Measurements of pilot cell performance using DSA (anode) and a Ti plate (cathodes) and an electrolyte composed of $5.5 \mathrm{M}$ $\mathrm{NaClO}_{3}$ and $2 \mathrm{M} \mathrm{NaCl}$ in deionized water (constant $\mathrm{pH}$ of 6.5). (a) Cathodic current efficiency. (b) $\mathrm{O}_{2}$ evolution rate. (c) Hypochlorite concentration $\left(\mathrm{C}_{\mathrm{NaClO}}\right)$. (d) Anodic current efficiency. (e) Cell potential. (f) Energy consumption. Data points were obtained after a

Figure $2 \mathrm{a}$ shows the values and trends of the cathodic current efficiency (CCE). In the absence of molybdate, the CCE increases as a function of increasing chromate concentration. Likely, the cathodic film of $\mathrm{CrO}_{x}$ grows to thicker quantities if the chromate concentration increases, leading to an improvement in performance [21]. Interestingly, in the presence of molybdate (triangles, black solid line), CCEs of $>90 \%$ are obtained already at very low chromate concentrations. Compared to the molybdatefree electrolyte, this resembles an increase in CCE of $4 \%$, indicating that molybdate-electrolyte additives enhance the selectivity towards the hydrogen evolution reaction [14]. For electrolytes containing $270 \mu \mathrm{M}$ of chromate, no statistical difference between experiments performed with or without molybdate is obtained, as the increase in CCE with increasing chromate concentration has a lower slope in the presence of molybdate. Using varying molybdate concentrations at a fixed chromate concentration of $27 \mu \mathrm{M}$ steady-state was achieved. Black values depict values as a function of $\mathrm{Cr}^{\mathrm{VI}}$ concentration (bottom $x$-axis) with $80 \mathrm{mM}$ of molybdate (solid, black triangle) and without molybdate (dotted, black square). Blue lines (solid, black star) show values as a function of molybdate concentration at a fixed $\mathrm{Cr}^{\mathrm{VI}}$ concentration of $27 \mu \mathrm{M}$

(stars, blue solid line) revealed that the current efficiency is already slightly improved for electrolytes containing only $0.8 \mathrm{mM}$ of molybdate. Further molybdate additions did not provide any additional enhancement.

The oxygen production at varying electrolyte composition is displayed in Fig. 2b. Chromate addition slightly increased the amount of oxygen in the cell gas in the concentration range studied. It is interesting to note that lower $\mathrm{O}_{2}$ rates are observed at high chromate concentrations $(21 \mathrm{mM}$, 1-6 $\mathrm{g} \mathrm{dm}^{-3}$ ) [20]. Such increase in oxygen in case of low chromate concentrations is likely induced by a sum of factors. First, the selectivity provided by chromate promotes a slight increase in the hypochlorite concentration. Secondly, at such small chromate concentration, the catalytic effect towards chlorate formation is absent [22-24]. Adding to this the weaker buffering capacity of the electrolyte and a change in anode selectivity caused by adsorption of $\mathrm{Cr}(\mathrm{VI})$ results in a higher oxygen concentration in the cell gas [25, 26]. 
An identical trend is observed in the presence of $80 \mathrm{mM}$ of molybdate, though the total amount of $\mathrm{O}_{2}$ increases by approximately $1 \%$. More importantly, the $\mathrm{O}_{2}$ concentration in the cell gas increases as a function of molybdate concentration at fixed chromate concentrations. This trend is in agreement with the activation of the anode towards water oxidation by deposition or adsorption of molybdate $[13,16]$. The homogeneous decomposition of hypochlorite to oxygen according to Eqs. 1 and 2, however, is most likely not contributing to the increase in oxygen level [24]:

$2 \mathrm{OCl}^{-} \rightarrow \mathrm{O}_{2}+2 \mathrm{Cl}^{-}$

$2 \mathrm{HClO} \rightarrow \mathrm{O}_{2}+2 \mathrm{Cl}^{-}+2 \mathrm{H}^{+}$

This in turn results in a decrease in hypochlorite concentration $\left[\mathrm{ClO}^{-}\right]$(Fig. 2c) and translates to a noticeable decrease in anodic current efficiency (ACE: Fig. 2d). Note that hypochlorite concentration $\left[\mathrm{ClO}^{-}\right]$represents the total amount of $\mathrm{ClO}^{-}$and $\mathrm{HClO}$ in the electrolyte, which is converted to $\mathrm{ClO}^{-}$in order to be titrated. Given that chromate is known to catalyse the disproportionation reaction (Eq. 3) forming chlorate [23, 27-29], the experimental results support the notion that high molybdate concentrations $(>80 \mathrm{mM})$ should be avoided for efficient chlorate production.

$2 \mathrm{HClO}+\mathrm{OCl}^{-} \rightarrow \mathrm{ClO}_{3}^{-}+2 \mathrm{Cl}^{-}+2 \mathrm{H}^{+}$

The overall cell potential is one of the most important parameters to address the economic viability of any electrochemical process. As indicated in Fig. 2e, the cell potential increases as a function of chromate concentration in the absence of molybdate (squares, black-dotted line). The increase is related to improved hydrogen evolution selectivity obtained for completely covering $\mathrm{CrO}_{x}$ films formed on the cathode [30]. Given the favourable thermodynamic potential and small overpotential of hypochlorite reduction, an enhanced $\mathrm{H}_{2}$ selectivity directly induces higher cell potentials. In the presence of $80 \mathrm{mM}$ molybdate (triangles, black solid line), the cell potential does not vary significantly with increasing chromate concentration. In fact, at low chromate concentrations $(<27 \mu \mathrm{M})$, the cell potential is higher compared to molybdate-free conditions. However, increasing chromate concentrations $(>27 \mu \mathrm{M})$, the determined cell potential in molybdate-containing electrolyte is smaller. At the highest chromate concentration, the cell voltage difference between molybdate-free and molybdate-containing electrolytes is significant $(170 \mathrm{mV})$. The improvement is caused by the activating effect of molybdate on the HER [14]. The cell potential even further decreased to $3.08 \mathrm{~V}$ in low molybdate and low chromate conditions $(0.8 \mathrm{mM}$ of molybdate and $27 \mu \mathrm{M}$ chromate). The apparently ben- eficial cell potential at low chromate concentrations in the absence of molybdate, however, can be caused by unwanted hypochlorite reduction occurring on the cathode.

To further verify the beneficial effect of chromate and molybdate electrolyte-additives, the energy consumption $\left(\mathrm{kWh}\right.$ ton $\left.^{-1}\right)$, taking into account the cell potential and the losses expressed by the cathodic and the anodic current efficiency, is calculated according to Eq. 4 [20] and is summarized in Fig. 2f:

Energy consumption $=\frac{m n F V}{M M t \varepsilon}$

Here, $m$ is the mass of chlorate in grams, $n$ is the number of moles, $F$ is Faraday's constant; $M M$ is the molar mass of chlorate; $t$ is time, and $\varepsilon$ is the total current efficiency, calculated using

$\varepsilon=\frac{A C E-(100-C C E)}{100}$

At low chromate concentrations $(<270 \mu \mathrm{M})$, the energy consumption increases upon addition of $80 \mathrm{mM}$ molybdate. At the highest chromate concentration $(270 \mu \mathrm{M})$, however, the energy consumption with or without molybdate in the electrolyte appears to be similar. Thus, at high chromate concentrations, the properties of the resulting $\mathrm{CrO}_{x}$ film dominate the electrochemistry of the cathode. At low chromate and varying molybdate concentration (blue line in Fig. 2f), the energy consumption is dominated by the beneficial effects induced by molybdate. Particularly, the improvement in cathodic current efficiency (CCE) induced by the activation of the cathode towards the HER [14] dominates the energy consumption. The beneficial effect of molybdate on the CCE does not scale with molybdate concentration. In fact, the energy consumption at high molybdate concentrations is dominated by the detrimental hypochlorite decomposition to oxygen. This leads to an overall decrease in energy efficiency with increasing molybdate concentration.

As all error bars, indicated in Fig. 2, represent absolute offsets between repeated experiments and do not affect the trends observed, it can be concluded that the performed experiments describe the effects of chromate and molybdate additions in the chlorate electrolyte accurately. Thus, the optimal electrolyte-additive composition for operation in low chromate conditions is determined to be $27 \mu \mathrm{M}$ chromate and $0.8 \mathrm{mM}$ molybdate. The process performance parameters for the optimized electrolyte composition are summarized in Table 2 (see Table 1 for key performance parameters using the state-of-the-art electrolyte composition). For the specific conditions, a decrease in energy consumption of $3-4 \%$ compared with electrolytes containing only chromate-additive $(300 \mu \mathrm{M})$ is obtained. 
Table 2 Performance parameters measured in the pilot plant for the optimized chlorate electrolyte using low chromate concentrations and molybdate as co-additive. The optimized electrolyte consists of $27 \mu \mathrm{M}\left(7.1 \mathrm{mg} \mathrm{dm}^{-3}\right)$ dichromate, $0.8 \mathrm{mM}\left(0.19 \mathrm{~g} \mathrm{dm}^{-3}\right)$ molybdate, $5.5 \mathrm{M}\left(580 \mathrm{~g} \mathrm{dm}^{-3}\right) \mathrm{NaClO}_{3}$ and $2 \mathrm{M}\left(120 \mathrm{~g} \mathrm{dm}^{-3}\right) \mathrm{NaCl}$. The measured parameters were obtained using Ti and DSA cathode and anode, respectively, at an electrolyte temperature of $348 \mathrm{~K}$ at current density of $3 \mathrm{kA} \mathrm{m}^{-2}$

\begin{tabular}{ll}
\hline Parameter & Value \\
\hline Cathodic current efficiency $(\%)$ & 89.3 \\
Anodic current efficiency (\%) & 91.5 \\
Cell potential $(\mathrm{V})$ & 3.09 \\
Energy efficiency $\left(\mathrm{kWh} \mathrm{ton}^{-1}\right)$ & 5765 \\
{$[\mathrm{NaClO}]\left(\mathrm{mM}\left(\mathrm{g} \mathrm{dm}^{-3}\right)\right)$} & $27.5(1.99)$ \\
$\mathrm{O}_{2}$ formation $\left(\mu \mathrm{M} \mathrm{s}^{-1}\right)$ & 1.67 \\
\hline
\end{tabular}

\section{Lab-Scale Validation}

To further elaborate on the positive effects of chromate and molybdate additives revealed in the process-oriented pilot plant experiments, specifically at low concentrations, analyses by use of an electrochemical quartz crystal microbalance (eQCM) and rotating ring disc electrode (RRDE) were employed.

Film deposition and growth was explored by eQCM experiments. Similarly to the measurements at pilot scale,
Ti electrodes were used and chromate and molybdate electrolyte additive concentrations were explored in the same concentration range (Fig. 3 and Figure S1). In the absence of any additive and for very low chromate concentrations, i.e. $2.7 \mu \mathrm{M}$ and $27 \mu \mathrm{M}$ of chromate, the mass change during constant potential measurements is negligible (Figure S1 and Figure S1a). Only at the highest chromate concentrations $(270 \mu \mathrm{M})$ a rapid mass gain at potentials cathodic of $-0.4 \mathrm{~V}$ vs. RHE is noticeable during voltammetry (Fig. 3a and S2b). As observed earlier for Pt and Au-based electrodes, film growth appears to be self-limited also in case of Ti electrodes [3, 31-34], and mass gain terminates at a total film mass of $1.9 \mu \mathrm{g} \mathrm{cm}^{-2}$ (note that data shown in Fig. 3a represent the mass gain obtained in successive experiments, and approx. $1.0 \mu \mathrm{g} \mathrm{cm}^{-2}$ has been deposited in prior experiments).For molybdate containing electrolyte, independent of the concentration $(80 \mathrm{mM}$ molybdate Fig. $3 \mathrm{~b}$ and $0.8 \mathrm{mM}$ molybdate Fig. 3c), the rate of film deposition is potential dependent. For all potentials used in constant current experiments, a linear increase in mass was observed, and the slope in mass gain increased with increasing cathodic potential. At the highest molybdate concentration ( $80 \mathrm{mM}$ : Fig. 3b), the initial rate of molybdate deposition is lower than the initial rate of chromate deposition. Still, film growth continues for the entire duration of the experiment which is in strong contrast to the film growth behaviour observed with chromate only. Even after
Fig. 3 Mass change over time as a function of deposition potential using Ti electrodes in solution of $1 \mathrm{M} \mathrm{NaOH}$ and $2 \mathrm{M} \mathrm{NaCl}$. The legend shows the deposition potential in $\mathrm{V}$ vs RHE; the arrow indicates the sequence of measurements. Electrolyte additive was (a) $270 \mu \mathrm{M} \mathrm{Cr}^{\mathrm{VI}}$, (b) $80 \mathrm{mM}$ molybdate, (c) $0.8 \mathrm{mM}$ molybdate before and after stepping into the HER regime and (d) $0.8 \mathrm{mM}$ molybdate and $27 \mu \mathrm{M} \mathrm{Cr}^{\mathrm{VI}}$, on clean $\mathrm{Ti}$ and after 4 min deposition with only $0.8 \mathrm{mM}$ molybdate at $-0.5 \mathrm{~V}$ subsequent to polarization allowing for hydrogen evolution to take place, i.e. denoted as "after HER"
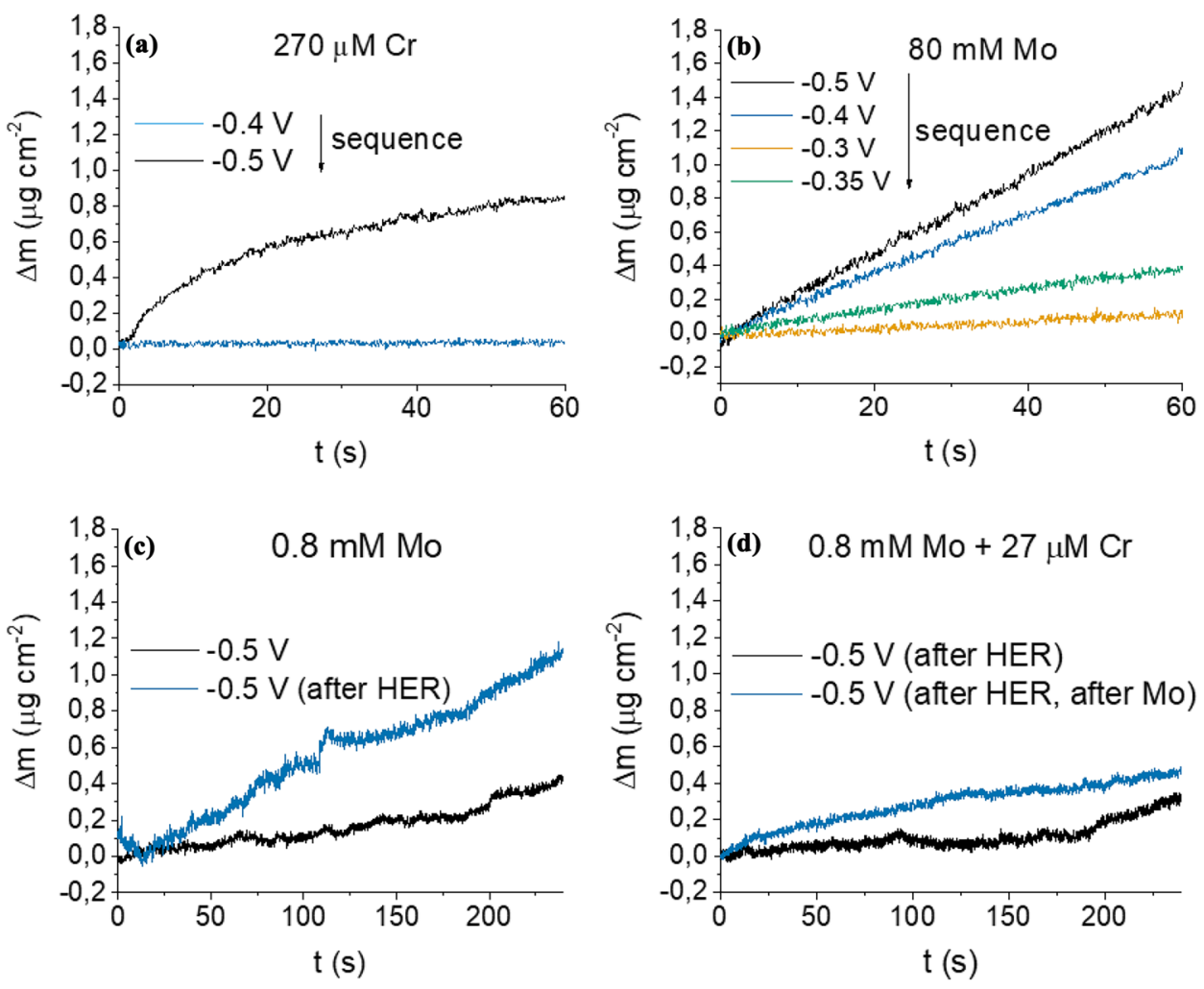
deposition of $5.9 \mu \mathrm{g} \mathrm{cm}^{-2}$ of $\mathrm{MoO}_{x}$, film growth appears to continue. Interestingly, deposition of molybdate on a preformed $\mathrm{MoO}_{\mathrm{x}}$ film resulted in further film growth at even larger rates (Fig. 3c, d).

When using electrolytes containing both molybdate and chromate in high concentrations (Figure S3), the mass gain resembles the deposition trends observed for electrolytes containing $270 \mu \mathrm{M}$ of chromate only. Pre-deposition of a $1.9 \mu \mathrm{g} \mathrm{cm}^{-2} \mathrm{CrO}_{x}$ film inhibits successive deposition of $\mathrm{MoO}_{x}$ (Figure S4a). Thus, molybdate reduction is inhibited in the presence of $\mathrm{CrO}_{x}$. In contrast, deposition of $\mathrm{CrO}_{x}$ from chromate-containing solutions onto pre-formed $\mathrm{MoO}_{x}$ films is still feasible (Figure $\mathrm{S} 2 \mathrm{~d}$ ).

Using mixed molybdate $(0.8 \mathrm{mM})$ and chromate $(27 \mu \mathrm{M})$ additives in concentrations similar to the optimum conditions used in the pilot trail experiments, eQCM measurements revealed that film growth is only partially inhibited (Fig. 3d). Overall, the deposition rate is slower compared to molybdateonly conditions and film growth is not self-terminating as in chromate-only conditions. Therefore, a mixed-film deposition behaviour is observed, likely resulting in a modified film structure of hybrid nature in agreement with the pilot trial investigations. In fact, molybdate is known to favour co-deposition [14]. Even though the general trends observed with the eQCM match pilot-scale operation, the relative mole ratio between additives and surface area of the electrode is different explaining observed differences in film growth behaviour. Furthermore, geometry and mass transfer conditions will also alter the precise electrolyte-additive concentrations [18, 19].

Kinetics and selectivity for hydrogen evolution in the presence and absence of electrolyte-additives and hypochlorite were analysed using polarization curves obtained with Ti-RDE. The concentrations of chromate and molybdate resemble the concentration of the best performed pilot cell, i.e. $27 \mu \mathrm{M}$ and $0.8 \mathrm{mM}$, respectively. Before each measurement, the cathode was pre-polarized for $5 \mathrm{~min}$ at $-0.6 \mathrm{~V}$ to allow for film formation. Figure 4 a shows polarization curves recorded without hypochlorite to study the hydrogen evolution exclusively. Without molybdate and/or chromate electrolyte-additives (Fig. 4a, black line), HER occurs at potentials negative of $-1.0 \mathrm{~V}$ vs. RHE. In the presence of molybdate, the potential required to drive HER decreased by approximately $500 \mathrm{mV}$, in line with the drop in cell potential in pilot plant measurements (Fig. 2e) [13, 14]. To rule-out a strong influence of a potential-drop induced by molybdate reduction, polarization curves were measured using ex situ modified Ti-electrodes (Figure S5). Clearly, the observed effects are due to improved kinetics for HER rather than additive-reduction. For chromate-containing electrolyte (Fig. 4a, yellow line), at higher current densities, lower potentials are required compared to the blank measurements performed at the bare Ti electrode. A mixture of both additives (green line) behaves much like chromate, as expected from eQCM experiments. Interestingly, polarization curves measured at higher chromate $(270 \mu \mathrm{m})$ and molybdate $(80 \mathrm{mM})$ concentrations (Figure S6) appear to be similar. This contrasts with the eQCM measurements and attributed to the vastly increased mass transport during RDE measurements.

Figure 4 iR-drop corrected polarization curves at $2500 \mathrm{rpm}$ in $0.1 \mathrm{M} \mathrm{NaOH}, 2 \mathrm{M} \mathrm{NaCl}, 27 \mu \mathrm{M}$ chromate and $0.8 \mathrm{mM}$ molybdate. The grey dashed line indicates the current density industrial setups operate at. The electrode was polished Ti, pre-polarized for $5 \mathrm{~min}$ at $-0.6 \mathrm{~V}$ vs RHE, without hypochlorite (a), or with $80 \mathrm{mM}$ hypochlorite (b).

In the presence of hypochlorite (Fig. 4b) for bare $\mathrm{Ti}$ electrodes, a clear decrease in potential is observed (grey line) compared to an electrolyte without hypochlorite (black line) entirely caused by hypochlorite reduction [9]. At high current densities, this process becomes mass transport limited (Figure S6), and HER occurs simultaneously. In the presence of molybdate (Fig. 4b, blue line), the activation of the cathode for HER is superimposed
Fig. 4 iR-drop corrected polarization curves at 2500rpm in $0.1 \mathrm{M} \mathrm{NaOH}, 2 \mathrm{M} \mathrm{NaCl}$, $27 \mu \mathrm{M}$ chromate and $0.8 \mathrm{mM}$ molybdate. The greydashed line indicates the current density industrial setups operate at. Theelectrode was polished $\mathrm{Ti}$, pre-polarized for 5 minutes at $-0.6 \mathrm{~V}$ vs RHE. (a)without hypochlorite; (b) with $80 \mathrm{mM}$ hypochlorite.
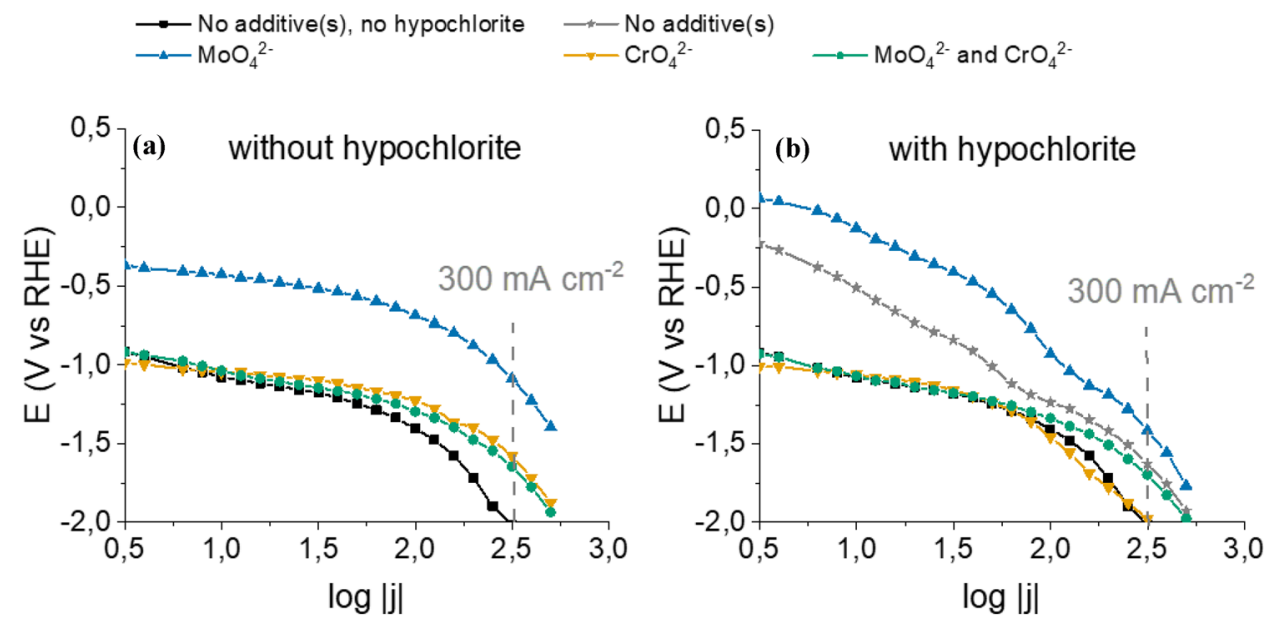
by hypochlorite reduction. Thus, Ti modification using $\mathrm{MoO}_{x}$-thin films is not effective for blocking hypochlorite reduction. In the presence of chromate, the hypochlorite reduction is entirely suppressed (yellow line) due to formation of the $\mathrm{CrO}_{x}$ film, resulting in a polarization curve similar to that of bare $\mathrm{Ti}$ in the absence of hypochlorite. Again, using a mixture of electrolyte-additives is effective for suppression of hypochlorite reduction and even enables operation at higher current densities. More precisely, addition of $0.8 \mathrm{mM}$ molybdate as co-additive to $27 \mu \mathrm{M}$ chromate results in a $290-\mathrm{mV}$ decrease in cathodic potential to maintain current densities of $300 \mathrm{~mA} \mathrm{~cm}{ }^{-2}$. For comparison, a decrease in cell potential of appr. $90 \mathrm{mV}$ was observed for similar additive concentrations in the pilot plant measurements. Combined eQCM and RDE measurements suggest that this potential drop is caused by a hybrid thin film deposited from mixed additive electrolytes preventing hypochlorite reduction and additionally improving the HER. In fact, the large potential drop observed in RDE measurements might indicate that further tweaking of the (co-)additive ratio may result in additional improvements on pilot scale. Still, it is important that different operating conditions, e.g. temperature, mass transport and $\mathrm{pH}$, also influence the performance of the modified electrodes.

\section{Conclusions}

Operation of the electrochemical chlorate process at low chromate concentrations was studied both at pilot and lab scale using molybdate as potential co-additive to enhance process economics. Overall, it is shown that electrolyte engineering is a valid strategy to improve process performance and using $27 \mu \mathrm{M}$ chromate and $0.8 \mathrm{mM}$ molybdate as electrolyte-additives resulted in favourable energy consumption. Compared to additive-free operation, i.e. only chromate-additive $(370 \mu \mathrm{M})$ and no molybdate-additive, a decrease in energy consumption of 3-4\% is obtained caused by improvements of the cell potential and the cathodic current efficiency. EQCM and RDE measurements additionally aid to the fundamental understanding of the results obtained at pilot plant level and suggest that fundamental and industrial development should be pursued together, i.e. it is revealed that films of hybrid nature are deposited at the concentrations of interest. These films allow for selectivity (chromate) and improved HER activity (molybdate) simultaneously. Despite the limitations of pilot plant operation at high molybdate concentrations (promoting oxygen formation) with further optimization of hybrid films, cell performance requirements for industrial application might be achievable, while maintaining a 1000-fold reduction in chromate concentration compared to the current state-ofthe-art operation.

Abbreviations ACE: Anodic current efficiency; CCE: Cathodic current efficiency; EQCM: Electrochemical quartz crystal microbalance; RRDE: Rotating ring disc electrode

Supplementary Information The online version contains supplementary material available at https://doi.org/10.1007/s12678-021-00666-7.

Acknowledgements The authors thank Mats Widlock for his support and scientific discussions.

Author Contribution The manuscript was written through contributions of all authors. All authors have given approval to the final version of the manuscript.

Funding This research received funding from The Netherlands Organization for Scientific Research (NWO) in the framework of the fund New Chemical Innovations, project ELECTROGAS (731.015.204), with financial support of Nouryon, Shell Global Solutions, Magneto Special Anodes (an Evoqua Brand) and Elson Technologies.

\section{Declarations}

Competing interests The authors declare no competing interests.

Open Access This article is licensed under a Creative Commons Attribution 4.0 International License, which permits use, sharing, adaptation, distribution and reproduction in any medium or format, as long as you give appropriate credit to the original author(s) and the source, provide a link to the Creative Commons licence, and indicate if changes were made. The images or other third party material in this article are included in the article's Creative Commons licence, unless indicated otherwise in a credit line to the material. If material is not included in the article's Creative Commons licence and your intended use is not permitted by statutory regulation or exceeds the permitted use, you will need to obtain permission directly from the copyright holder. To view a copy of this licence, visit http://creativecommons.org/licenses/by/4.0/.

\section{References}

1. B. Endrődi, N. Simic, M. Wildlock, A. Cornell, Electrochim. Acta 234, 108 (2017)

2. B.V. Tilak, K. Tari, C.L. Hoover, J. Electrochem. Soc. 135, 1386 (1988)

3. G. Lindbergh, D. Simonsson, J. Electrochem. Soc. 137, 3094 (1990)

4. E. C. Agency, Authoirzation List Sodium Dichromate (European Chemicals Agency (ECHA), (2015)

5. H. Kim, B. Endrődi, G. Salazar-Alvarez, A. Cornell, A.C.S. Sustain, Chem. Eng. 7, 19415 (2019)

6. J. Gustavsson, L. Nylén, A. Cornell, J. Appl. Electrochem. 40, $1529(2010)$

7. L. Nylén, J. Gustavsson, A. Cornell, J. Electrochem. Soc. 155, E136 (2008)

8. J. Gustavsson, G. Lindbergh, A. Cornell, Int. J. Hydrogen Energy 37, $9496(2012)$

9. B. Endrődi, S. Sandin, V. Smulders, N. Simic, M. Wildlock, G. Mul, B.T. Mei, A. Cornell, J. Clean. Prod. 182, 529 (2018) 
10. B. Endrődi, V. Smulders, N. Simic, M. Wildlock, G. Mul, B. Mei, A. Cornell, Appl. Catal. B Environ. 244, 233 (2019)

11. O. Gharbi, S. Thomas, C. Smith, N. Birbilis, Npj Mater. Degrad. 2, $12(2018)$

12. U.Č Lačnjevac, B.M. Jović, L.M. Gajić-Krstajić, J. Kovač, V.D. Jović, N.V. Krstajić, Electrochim. Acta 96, 34 (2013)

13. M. Li, Z. Twardowski, F. Mok, N. Tam, J. Appl. Electrochem. 37, 499 (2007)

14. J. Gustavsson, C. Hummelgard, J. Backstrom, I.O. Wallinder, S.M. Rahman, G. Lindbergh, S. Eriksson, A. Cornell, J. Electrochem. Sci. Eng. 2, 105 (2012)

15. F.J. Presuel-Moreno, M.A. Jakab, J.R. Scully, J. Electrochem. Soc. 152, B376 (2005)

16. J. Gustavsson, G. Li, C. Hummelgard, J. Backstrom, A. Cornell, J. Electrochem. Sci. Eng. 2, 185 (2012)

17. M. Rosvall, K. Hedenstedt, A. Sellin, J. Gustavsson, and A. Cornell, W02010/130546A1 (2010).

18. C.J. Brown, D. Pletcher, F.C. Walsh, J.K. Hammond, D. Robinson, J. Appl. Electrochem. 22, 613 (1992)

19. Á. Anglada, A.M. Urtiaga, I. Ortiz, J. Hazard. Mater. 181, 729 (2010)

20. K. Hedenstedt, N. Simic, M. Wildlock, E. Ahlberg, J. Appl. Electrochem. 47, 991 (2017)

21. J. Wulff, A. Cornell, J. Appl. Electrochem. 37, 181 (2006)

22. J. Wanngård, M. Wildlock, Chem. Eng. Res. Des. 121, 438 (2017)
23. J. Kalmár, M. Szabó, N. Simic, I. Fábián, Dalt. Trans. 47, 3831 (2018)

24. S. Sandin, R.K.B. Karlsson, A. Cornell, Ind. Eng. Chem. Res. 54, $3767(2015)$

25. L. Nylén, M. Behm, A. Cornell, G. Lindbergh, Electrochim. Acta 52, 4513 (2007)

26. B. Nikolić, M. Jaksić, S. Maksić, A. Despić, Croat. Chem. Acta 44, 61 (1972)

27. B. Endrődi, S. Sandin, M. Wildlock, N. Simic, A. Cornell, J. Chem. Technol. Biotechnol. 94, 1520 (2019)

28. J. Wanngård, Chem. Eng. Res. Des. 121, 438 (2017)

29. M. Spasojević, D. Marković, T. Trišović, M. Spasojević, J. Electrochem. Soc. 165, E8 (2018)

30. A. Gomes, N. Simic, M. Wildlock, A. Martinelli, E. Ahlberg, Electrocatalysis 9, 333 (2018)

31. A. Cornell, G. Lindbergh, D. Simonsson, Electrochim. Acta 37, $1873(1992)$

32. W.J. Clark, R.L. McCreery, J. Electrochem. Soc. 149, B379 (2002)

33. A.A. Tidblad, J. Martensson, Electrochim. Acta 42, 389 (1997)

34. V. Smulders, N. Simic, A. S. O. Gomes, B. Mei, and G. Mul, Electrochim. Acta 296, (2019).

Publisher's Note Springer Nature remains neutral with regard to jurisdictional claims in published maps and institutional affiliations. 